\title{
ANTITUMOR EFFECT OF THE CHALCONE ANALOGUE, (E) - 1- (4-ETHOXY-3-METHOXYPHENYL) -5- METHYLHEX-1-EN-3-ONE ON HELA CELL LINE
}

Jovan Lukovic ${ }^{1}$, Marina Mitrovic ${ }^{2}$, Ivanka Zelen², Petar Čanovic ${ }^{2}$, Milan Zaric ${ }^{2}$ and Ivana Nikolic ${ }^{2}$ ${ }^{1}$ Faculty of Medical Sciences, University of Kragujevac, Kragujevac, Serbia

${ }^{2}$ Department of Biochemistry, Faculty of Medical Sciences, University of Kragujevac, Serbia

\author{
ANTITUMORSKI EFEKAT ANALOGA HALKONA (E) -1- \\ (4-ETOKSI-3-METOKSIFENIL) -5- METILHEKS-1-EN-3-ONA \\ NA HELA TUMORSKE ĆELIJE \\ Jovan Luković ${ }^{1}$, Marina Mitrović ${ }^{2}$, Ivanka Zelen ${ }^{2}$, Petar Čanović ${ }^{2}$, Milan Zarić $^{2}$ i Ivana Nikolić ${ }^{2}$ \\ ${ }^{1}$ Univerzitet u Kragujevcu, Srbija, Fakultet medicinskih nauka, Kragujevac, Srbija \\ ${ }^{2}$ Univerzitet u Kragujevcu, Srbija, Fakultet medicinskih nauka, Katedra biohemije, Kragujevac, Srbija
}

\begin{abstract}
Chalcones represent precursor compounds for flavonoids biosynthesis in plants. Chalcones, 1,3-diaryl-2-propen1-ones, have unique chemical structure with conjugated double bonds and delocalized $\pi$-electron system on both aromatic rings. Various studies have shown that chemical structure of chalcone is responsible for their antitumor effect. In our study, we have examined the antitumor effect of chalcone analogue (E) -1- (4-ethoxy-3-methoxyphenyl) -5methylhex-1-en-3-one (CH) on HeLa cells. The antitumor efficiency of different $\mathrm{CH}$ concentrations was compared to the antitumor effects of dehydrozingerone and cisplatin. The viability of the cells was evaluated using MTT assay; type of the cell death was evaluated by Annexin V-FITC/7-AAD staining using FACS analysis; morphology changes of treated cells were visualized and compared to untreated cells using phase contrast microscopy. The result of our research showed that $\mathrm{CH}$ have a stronger antitumor compared to the effect both of dehydrozingerone and cisplatin. Our results indicated that chalcone analogue induced cell death via activation of apoptosis more powerfully compared to the apoptosis induced with dehydrozingerone and cisplatin.
\end{abstract}

Keywords: cervical cancer, cytotoxicity, apoptosis, morphology.

\section{SAŽETAK}

Halkoni predstavljaju prekursore biosinteze flavonoida u biljkama. Halkoni, 1,3-diaril-2-propen-1-oni, poseduju jedinstvenu hemijsku strukturu sa konjugovanim dvogubim vezama $i$ delokalizovanim $\pi$-elektronskim sistemom na oba aromatična prstena. Različite studije su pokazale da je hemijska struktura halkona odgovorna za njihov antitumorski efekat. U našem istraživanju ispitivan je antitumorski efekat analoga halkona (E) -1- (4-etoksi-3-metoksifenil) -5- metilheks-1-en-3-one (CH) na tumorskim HeLa ćelijama. Antitumorska efikasnost ispitivanog analoga halkona, u različitim dozama upoređivana je sa antitumorskim efektima dehidrozingerona $i$ cisplatine. Vijabilnost tumorskih ćelija odredivana je upotrebom MTT testa; tip ćelijske smrti upotrebom Annexin V-FITC/7-AAD bojenja pomoću FACS analize; morfološke promene tretiranih $i$ kontrolnih ćelija vizualizovane su upotrebom faznog kontrastnog mikroskopa. Rezultati našeg istraživanja pokazali su da analozi halkona, $\mathrm{CH}$ ispoljavaju jači antitumorski efekat u odnosu na dehidrozingeron $i$ cisplatinu. Naši rezultati ukazuju na to da analozi halkona efikasnije indukuju ćelijsku smrt u odnosu na dehidrozingeron $i$ cisplatinu.

Ključne reči: karcinom cerviksa, citotoksičnost, apopto$z a$, morfologija

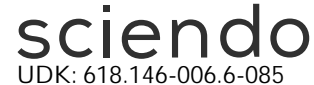
615.322:547.972.2

SEr J Exp Clin Res 2019; 20 (3): 215-221

DOI: 10.2478/SJECR-2018-0048
Corresponding author: Ivanka Zelen, Svetozara Markovića 69, 34000 Kragujevac: 034306 800; ext 101 ivankazelen@gmail.com; 


\section{INTRODUCTION}

Cervical cancer $(\mathrm{CC})$ represents leading cause of cancer related death in women worldwide influencing women during their reproductive age $(\mathrm{Li}, \mathrm{Bau}, \& \mathrm{Bao}$, 2018). As cervical squamous cell carcinoma this malig nancy exhibiting high morbidity and mortality. Cervical cancer is the cause of approximately 200,000 deaths worldwide (Muñoz et al., 2003). Based on the information from 2012, Serbia is in the third place for the mortality from CC. In the period (1991-2011) the average age-standardized mortality rate was 7.03 per 100.000 . The average age standardized mortality rate was from 6.05 in 1991 to 8.17 in 2008 (Naumovic, Miljus, Djoric, Zivkovic, \& Perisic, 2015). More than $80 \%$ of early stages of CC can be cured by surgery and chemotherapy, with possibility of recurrence of CC (Ball \& Madden, 2003). However, both chemotherapy and radiation cause serious adverse effects, therefore anti-cancer therapeutic efficiency of the new compounds is needed to treat cancer. By using anti-cancer therapeutics, cancer cell death can be caused by the induction of apoptosis, necrosis and autophagy.

Chalcones and their analogues represents natural or synthetic 1,3-diaryl-2-propenones with significant delocalization of the electron throughout the chalcone system, the combination of excellent charge-carrier mobility and a high stability structure. Chalcone molecules which are intermediate precursors to all flavonoid compounds along with their a $\pi$-conjugated system provides a large charge-transfer with appropriate substituent groups (Wu, Liu, \& Zhu, 2010)(Mahapatra, Bharti, \& Asati, 2015). This type of chemical structure of chalcones is responsible for their anti-tumor (Mahapatra et al., 2015)(Alibeiki, Jafari, Karimi, \& Peeri Dogaheh, 2017), anti-inflammatory (K. Sahu, S. Balbhadra, Choudhary, \& V. Kohli, 2012)(Kim et al., 2015) and anti-oxidant effects (Lahsasni, Al Korbi, \& Aljaber, 2014)(Kim et al., 2015).

In our research, we used cisplatin and dehydrozingerone as reference substances. The cisplatin has a clinical application and is used to treatment malignant tumors of various tissues such as colon, lung, cervix, breast, ovaries and testicles (Taguchi, Nazneen, Abid, \& Razzaque, 2005). The dehydrozingerone shows anti-tumor, anti-inflammatory and anti-oxidant effect on human tumor cells, e.g. HeLa, A549, LS174 и MDA-MB-231cell lines (Burmudžija et al., 2017)(Kubra, Bettadaiah, Murthy, \& Rao, 2014).

In our study, we examined the antitumor effect of chalcone analogue (E) -1- (4-ethoxy-3-methoxyphenyl) -5- methylhex-1-en-3-one (CH) that was previously synthesized in the procedures described by Muškinja et al., (Muškinja, Ratkovi, Rankovi, \& Kosani, 2016). Here, for the first time, we report the anti-tumor effect of $\mathrm{CH}$ on $\mathrm{HeLa}$ cell line.

\section{MATERIAL AND METHODS}

\section{Cell line, compounds and reagents}

The cell line utilized in this study, HeLa (human cervical carcinoma cell line), was purchased from the American Type Culture Collection (ATCC CCL-2 ${ }^{m}$ ). The HeLa cell line was cultured in complete growth DMEM medium (Sigma Aldrich D5671). The cells were maintained at $37^{\circ} \mathrm{C}$ in a humidified atmosphere of $5 \% \mathrm{CO}_{2}$. Both, the synthesized chalcone analogue $(\mathrm{CH})$ and dehydrozingerone were a gift from colleagues, Faculty of Chemistry, University of Kragujevac. Cisplatin was obtained from the Calbiochem (CAS 15663-27-1). Annexin V-FITC and 7-AAD (7-aminoactinomycin-D) was purchased from Abnova (KA3806). Chloroquine (obtained from the Sigma Aldrich, C6628) was dissolved in ultrapure water at a concentration of $100 \mu \mathrm{M}$, and then in DMEM at a final concentration of $20 \mu \mathrm{M}$. The chalcone analogue and referent substances (cisplatin, cysPt and dehydrozingerone, DHZ) were dissolved in DMSO (final concentration of DMSO was less than $0.5 \%$ ).

\section{MTT assay}

Cells were seeded in a 96-well plate at $5 \times 10^{3}$ cells/well, incubated for 24 and $48 \mathrm{~h}$ with different concentrations of $\mathrm{CH}(0.3,1,3,10,30,100$ and $300 \mu \mathrm{M})$ and referent substances - cysplatin and dehydrozingerone (tested concentrations were $3,10,30$ and $100 \mu \mathrm{M}$ ) in triplicate. After treatment, the supernatant was removed and MTT was added to each (100 $\mathrm{\mu l}$ medium; $0.5 \mathrm{mg} / \mathrm{ml}$ MTT). After incubation for $3 \mathrm{~h}$ MTT was discarded and $150 \mu$ DMSO was added to each well. The absorbance was measured at $595 \mathrm{~nm}$ using a micro-plate reader (Zenyth 3100, Anthos Labtec Instruments). The percentage of cytotoxic cells was calculated using the formula: Cytotoxicity $(\%)=(1-(\exp$. group $(\mathrm{ABS})) /($ control group (ABS)) x 100). The IC50 values of investigated substances were calculated using Microsoft Office Excel, using the equation of linear dependence.

\section{Annexin V-FITC/7-AAD staining}

In order to determine the type of the cell death induced by $\mathrm{CH}, \mathrm{HeLa}$ cells were seeded in 24 -well plate $\left(1 \times 10^{5}\right.$ cells/ well) and treated with $\mathrm{IC}_{50}$ values of $\mathrm{CH}$ during $48 \mathrm{~h}$. The $\mathrm{IC}_{50}$ values both of cisplatin and dehydrozingerone were used as a positive control. To examine the influence of autophagy on the percentage of apoptotic cells, pretreatment with $C Q$ was performed on experimental and control cell group. After treatment, cells were trypsinized, resuspended with Annexin binding buffer and incubated with $10 \mu \mathrm{l}$ of Annexin V-FITC and $20 \mu \mathrm{L}$ of 7-AAD for $15 \mathrm{~min}$ in the dark. Following incubation and addition of $400 \mu$ l binding buffer, the cells were analyzed by flow cytometer Cytomics FC500 (Beckman Coulter, USA) and expressed as percentage (\%) of apoptotic cells. 


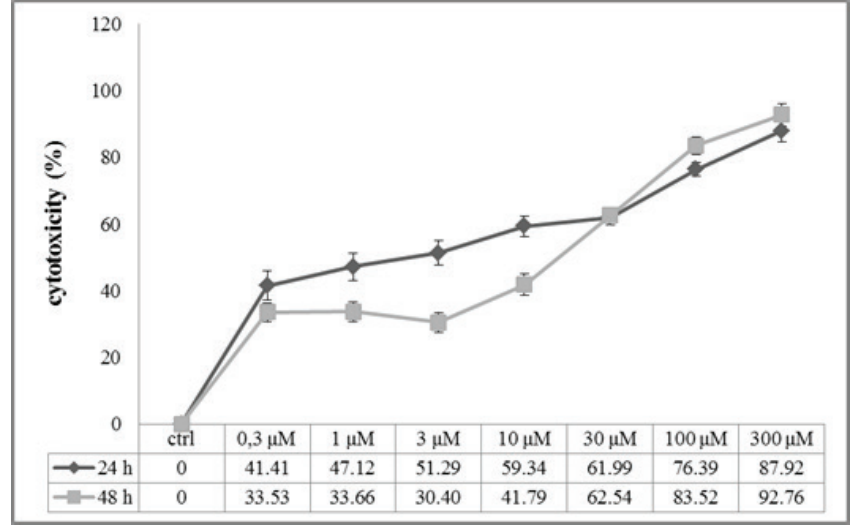

Figure 1. Sensitivity of cervical cancer cell line (HeLa) on $\mathrm{CH}$ treatment after 24 and $48 \mathrm{~h}$. The percentage of cytotoxicity cells was determined with MTT assay following treatment of cells with different concentrations of $\mathrm{CH}$ for 24 and $48 \mathrm{~h}$. The highest dose of $\mathrm{CH} 300 \mu \mathrm{M}$ resulted in nearly $90 \%$ of cytotoxic HeLa cells for 24 and 48 h, respectively. The lowest dose of $\mathrm{CH} 0.3 \mu \mathrm{M}$ resulted in $41.41 \%$ and $33.53 \%$ of cytotoxic HeLa cells for 24 and $48 \mathrm{~h}$, respectively.

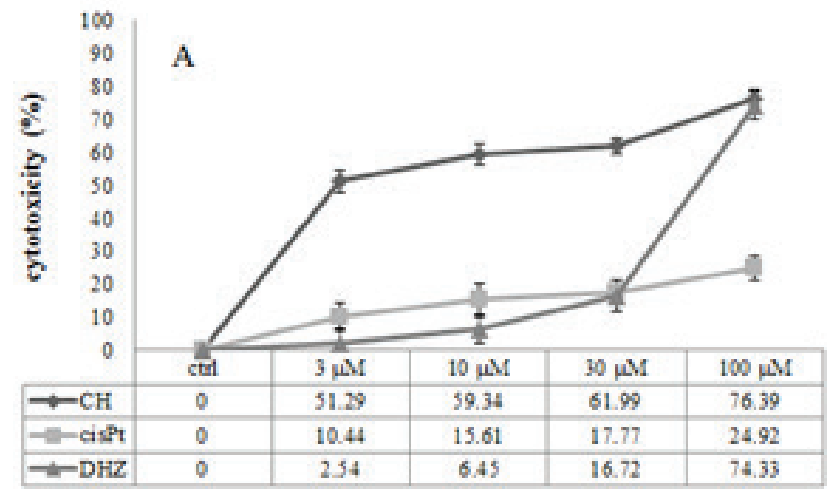

\section{RESULTS}

In our experiment, first, we evaluated the cytotoxic effect of $\mathrm{CH}$ on HeLa cells for 24 and $48 \mathrm{~h}$ using MTT assay at various concentrations of the substances. The results of MTT assay are shown in Figure 1. The data indicate that $\mathrm{CH}$ showed the concentration-dependent cytotoxic effect on HeLa cells after 24 and $48 \mathrm{~h}$ treatment. Application of the lowest investigated dose of $\mathrm{CH}$ resulted in $41.41 \%$ (after $24 \mathrm{~h}$ ) and $33.53 \%$ (after $48 \mathrm{~h}$ ), while the highest dose resulted in $87.92 \%$ (after 24 ) and $92.76 \%$ (after $48 \mathrm{~h}$ ) of cytotoxic HeLa cells, respectively. $48 \mathrm{~h}$ treatment with lower concentrations of $\mathrm{CH}(0.3-10 \mu \mathrm{M})$ resulted in a lower percentage of cytotoxic HeLa cells, while higher $\mathrm{CH}$ doses (from 30$300 \mu \mathrm{M}$ ) increased the percentage of cytotoxic HeLa cells.

A part of our research was the comparison of the cytotoxic effect of $\mathrm{CH}$ to the cytotoxic effects of both cisplatin and dehydrozingerone on the HeLa cells after 24 and 48 $\mathrm{h}$ treatment (Figure 2). Calculated $\mathrm{IC}_{50}$ values showed that

Figure 2. Comparison of cytotoxic effects of $\mathrm{CH}$ and referent substances (cisPt and DHZ) on cervical cancer cell line (HeLa) after 24h (A) and $48 \mathrm{~h}$ (B) treatments. The dose of $\mathrm{CH} 100 \mu \mathrm{M}$ resulted in $76.39 \%$ and $83.52 \%$ of cytotoxic HeLa cells for 24 and $48 \mathrm{~h}$ treatment, respectively.

\section{Morphological analysis}

In order to both investigate and compare the cytotoxic effect of tested substances $(\mathrm{CH}$, cisplatin and dehydrozingerone) on the morphology of treated and untreated HeLa cells, we have used contrast microscope. The HeLa cells were seeded in a 24-well plate and incubated for 48 h with $\mathrm{CH}$, dehydrozingerone and cisplatin $(3,10,30$ and $100 \mu \mathrm{M})$. Morphological changes of both experimental and control HeLa cells were visualized with phase contrast microscopy under $100 \mathrm{X}$ magnification on Olympus microscope (model BX51).

\section{Statistical analysis}

The significant differences between two groups were determined using paired t-test or by analysis of variance (ANOVA). All data are presented as mean \pm standard deviation and each experiment was repeated at least three times independently.

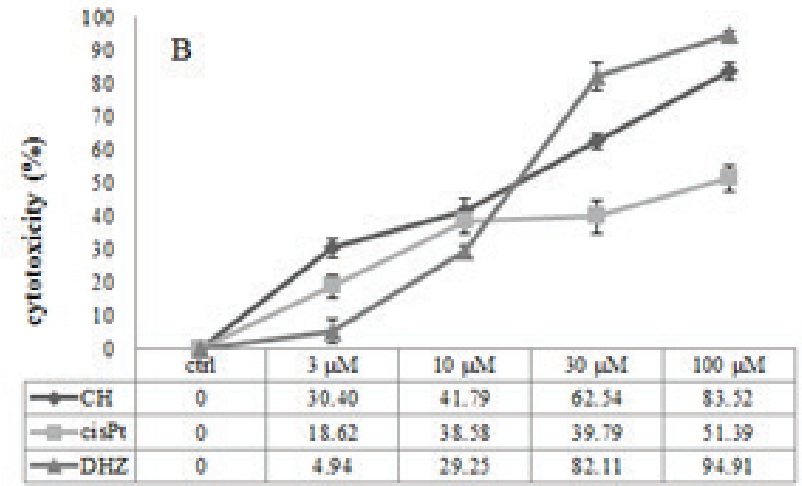

all investigated agents exhibited statistically significant cytotoxic effects on HeLa cells after 24 and 48 hours of treatment (Table 1). Our results showed that treatment of the cells with $\mathrm{CH}\left(\mathrm{IC}_{50}=2.55 \mu \mathrm{M}\right)$ during $24 \mathrm{~h}$ had more efficient cytotoxic effect compared to the cytotoxic effects of both cisplatin $(\mathrm{IC50}=9.70 \mu \mathrm{M})$ and dehydrozingerone $\left(\mathrm{IC}_{50}=3.61 \mu \mathrm{M}\right)$. However, our results clearly showed that difference in the cytotoxicity between $\mathrm{CH}\left(\mathrm{IC}_{50}=3.64 \mu \mathrm{M}\right)$ and cisplatin $\left(\mathrm{IC}_{50}=3.80 \mu \mathrm{M}\right)$ was insignificant, while dehydrozingerone $\left(\mathrm{IC}_{50}=2.41 \mu \mathrm{M}\right)$ exhibited more efficient cytotoxic effect on the HeLa cells after 48 hour treatment (Table 1).

Table 1. Calculated $\mathrm{IC}_{50}$ values for (E) -1- (4-ethoxy-3-methoxyphenyl) -5- methylhex-1-en-3-one and referent substances.

\begin{tabular}{|c|c|c|c|}
\hline HeLa IC $_{50}$ & CH & cisPt & DHZ \\
\hline $24 \mathrm{~h}$ & $2.55 \pm 1.23$ & $9.70 \pm 1.22$ & $3.61 \pm 2.16$ \\
\hline $48 \mathrm{~h}$ & $3.64 \pm 0.86$ & $3.80 \pm 0.4$ & $2.41 \pm 0.57$ \\
\hline
\end{tabular}



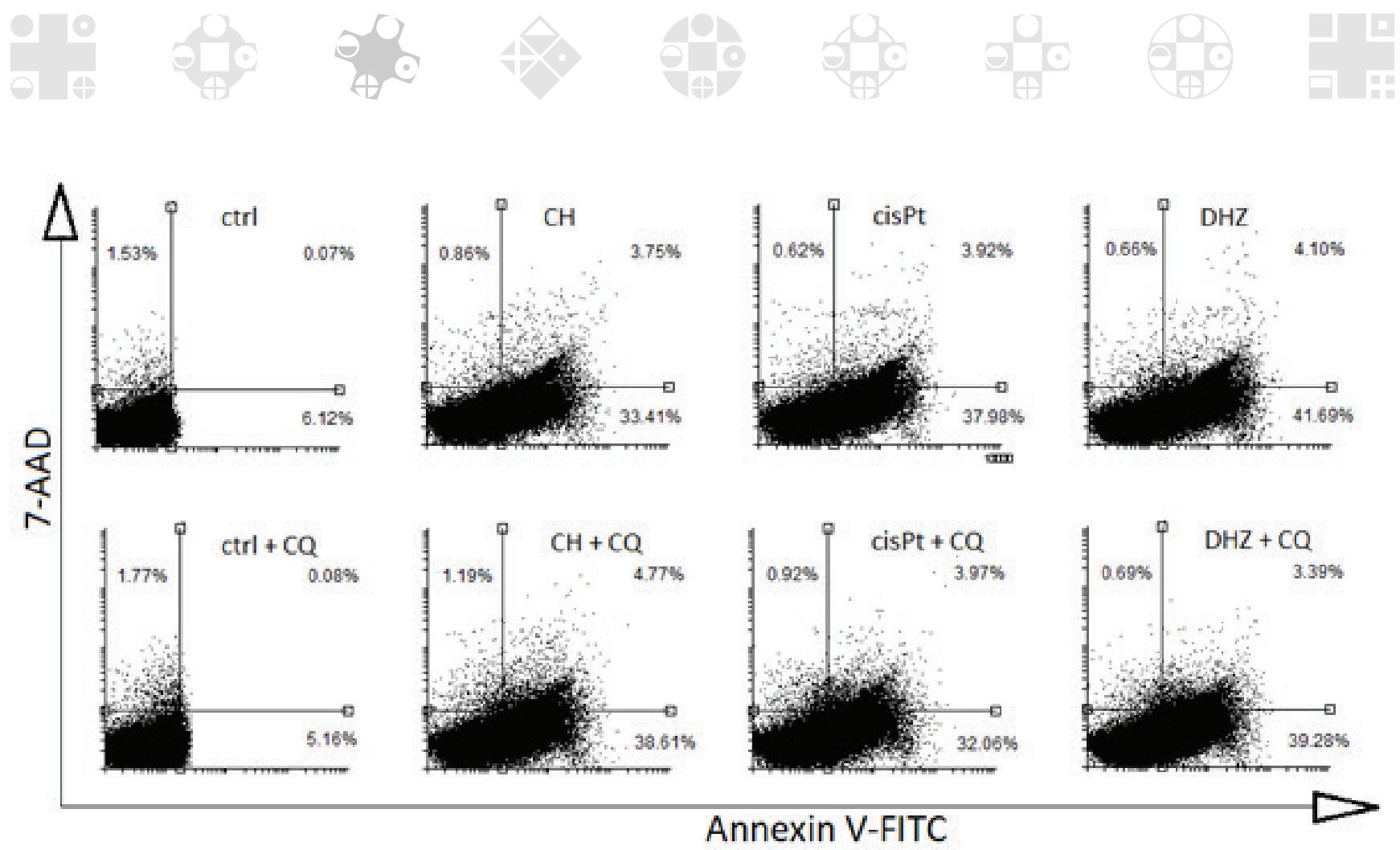

Figure 3. (E) -1- (4-ethoxy-3-methoxyphenyl) -5- methylhex-1-en-3-one induces apoptosis in HeLa cells. Flow cytometry analysis was used to determine the cell apoptosis and autophagy in HeLa cells after $48 \mathrm{~h}$ treatment with $\mathrm{IC}_{50}$ values of $\mathrm{CH}$, cisplatin and dehydrozingerone, as well as co-treatment with CQ $(20 \mu \mathrm{M})$ by Annexin V-FITC/7-AAD. Upper left square - necrosis (\%); bottom right square - early apoptosis (\%); upper right square - late apoptosis.

After determining the cytotoxic effect of $\mathrm{CH}$ and referent substances, we next examined the type of the cell death induced by all tested substances using FACS analysis. The HeLa cells were treated with $\mathrm{IC}_{50}$ values of investigated substances during 48 hour period (Figure 3). Our results showed that $\mathrm{CH}$ induced apoptosis in the HeLa cells. After $48 \mathrm{~h}$ treatment on the HeLa cells with $\mathrm{CH}\left(\mathrm{IC}_{50}=3.64\right.$ $\mu \mathrm{M})$, cisplatin $\left(\mathrm{IC}_{50}=3.80 \mu \mathrm{M}\right)$ and $\mathrm{DHZ}\left(\mathrm{IC}_{50}=2.41 \mu \mathrm{M}\right)$ we demonstrated that $33.41,41.69$ and $37.98 \%$ of cells were in early apoptosis; $3.75,4.10$ and $3.92 \%$ of cells were in late apoptosis; $0.86,0.66$ and 0.62 of cells were in necrosis, respectively (Figure 3).

In order to determine the type of cell death, we assessed influence of autophagy on percentage of apoptotic HeLa cells after the treatment with $\mathrm{CH}$. Co-treatment with $\mathrm{CH}(3.64 \mu \mathrm{M})$ and chloroquine $(\mathrm{CQ})(20 \mu \mathrm{M})$ was per-

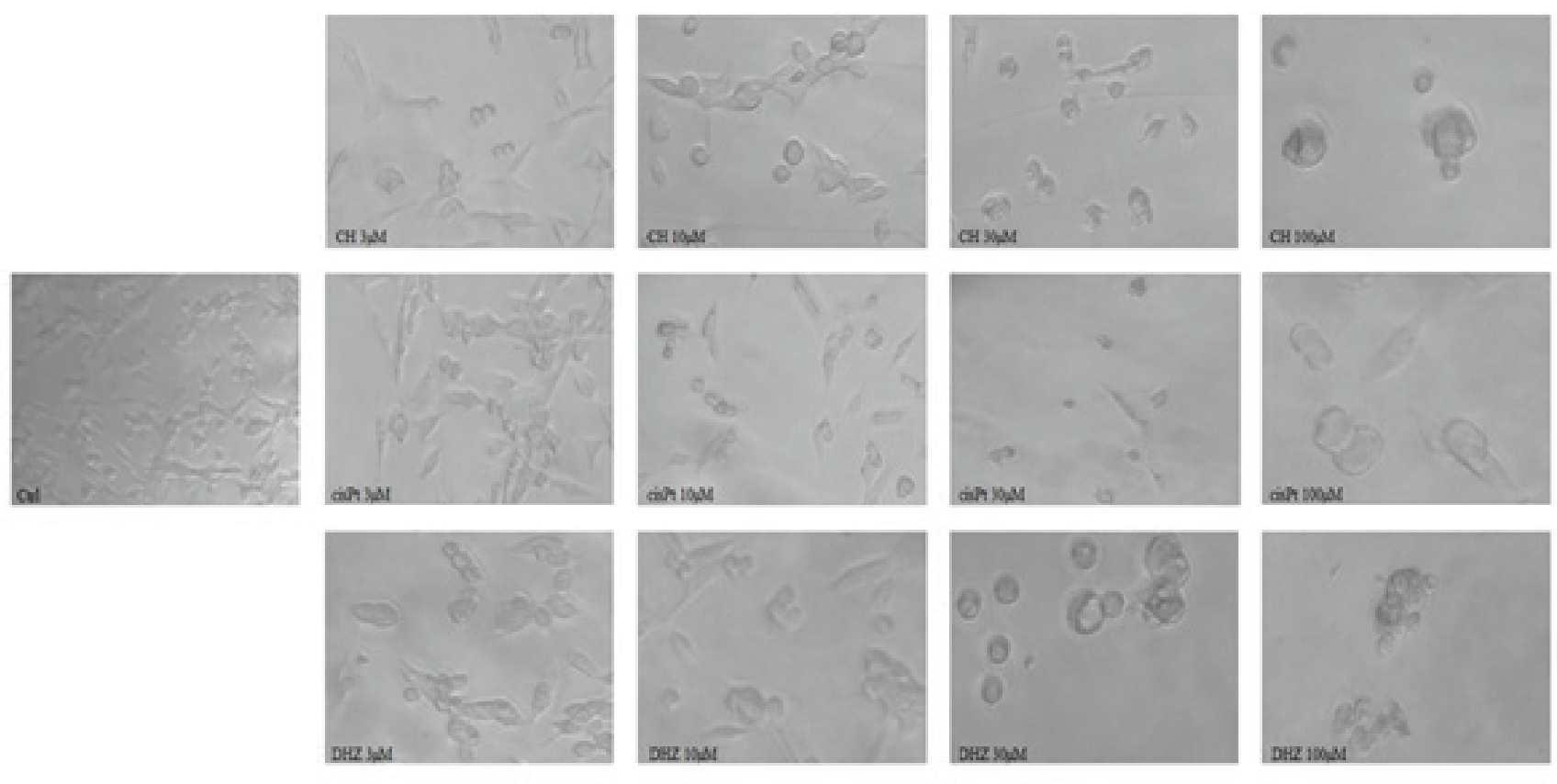

Figure 4. CH induces morphological changes of the HeLa cells in a dose-dependent manner that is consistent with MTT assay and FACS analysis. The HeLa cells were plated in 24 well plates and allowed to attach for $24 \mathrm{~h}$. Cells were exposed different concentrations of $\mathrm{CH}$, DHZ and cisplatin during $48 \mathrm{~h}$ period and morphology of the cells was analysed on microscope. After $48 \mathrm{~h}$ treatment with different concentrations of all investigated agents the morphology of the treated HeLa cells was significantly impaired compared to the untreated HeLa cells. 
formed on experimental HeLa cells for $48 \mathrm{~h}$ period. The percentage of apoptotic HeLa cells (early and late apoptosis) treated with $\mathrm{CH}$ was $37.16 \%$, while after co-treatment with chloroquine this percentage was $43.38 \%$ (Figure 3 ). Results indicated that addition of chloroquine was not significant for change in percentage of the apoptotic cells, and that the autophagy was most probably not involved in the mechanism of cytotoxic action of the $\mathrm{CH}$ and referent substances (Figure 3).

Changes in the morphology of the treated HeLa cells compared to control HeLa cells was evaluated after $48 \mathrm{~h}$ treatment with different doses of investigated substances. Our results showed that $\mathrm{CH}$ induced morphological changes of HeLa cells in dose dependent manner compared to the control group (Figure 4). These morphological changes were characterized in cell shrinkage cells, loss of shape cells and decrease in the number cells. Increasing the concentration of the $\mathrm{CH}$ from $3 \mu \mathrm{M}$ to $100 \mu \mathrm{M}$ resulted in a complete loss of cell morphology, which was in direct correlation with the results obtained by MTT assay and Annexin V-FITC/7-AAD staining.

\section{DISCUSSION}

Although today there are many options in cancer therapy, including surgery, radiotherapy and immunotherapy, treatment with anti-cancer drugs due to their non-selective cytotoxicity remains the primary treatment option. However, currently available anti-cancer drugs are cytotoxic for the normal cells resulting in a number of adverse effects. Therefore, it is necessary to synthesize new compounds with more efficient antitumor effect and highly selective antitumor. Chalcones are precursor compounds for flavonoids biosynthesis in plants. Changes in their chemical structure have offered a high degree of biological diversity that has proven to be useful for the development and synthesis of new medicinal agents. These medicinal agents exhibit lesser toxicity on normal cells and greater selectivity towards tumor cells compared to natural agents. For example, twelve structural Millepachine analogues (especially (3-hydroxy-4-methoxyphenyl)(5-methoxy-2,2dimethyl-2H-chromen-8-yl) methanone) showed more effective anti-proliferative activity on five human cancer cell lines (A549, HeLa, HCT 116, A2780 and MGC803) compared to natural compound, Millepachine (An, Zhang, Yan, Huang, \& Li, 2017).

Our research provides information of the antitumor effect of chalcone (E) -1- (4-ethoxy-3-methoxyphenyl) -5- methylhex-1-en-3-one $(\mathrm{CH})$ and its potential for development in anti-cancer therapy. The $\mathrm{CH}$ represents the structural analogue of dehydrozingerone which is a natural chalcone isolated from ginger (Kuo et al., 2005). The results of our study that of both the newly synthesized chalcone $(\mathrm{CH})$ and natural chalcone (DHZ) showed more effective cytotoxic effect on the HeLa cells compared to cisplatin, as shown in previously reported research (Kolundžija et al., 2014)(Ahmed, Abd El-Hafeez, Abbas, Abdelhamid, \& Abdel-Aziz, 2018). Also, our results are in correlation with previous studies that reported the cytotoxic effect of various chalcone analogues on the HeLa cells (Kolundžija et al., 2014)(L. Zhao, Mao, Hong, Yang, \& Liu, 2015)(Zhang et al., 2015). Results of the study performed by Zhang et al. indicated that different chalcone analogues exhibited effective cytotoxic effect on HeLa cells with $\mathrm{IC}_{50}$ values ranging from 1.4 to $6.8 \mu \mathrm{M}$ (Zhang et al., 2015). Calculated $\mathrm{IC}_{50}$ values for our $\mathrm{CH}$ substance was from 2.55 and 3.64 $\mu \mathrm{M}$, respectively.

Following MTT assay and determination of cytotoxic effects of $\mathrm{CH}$ analogues on the HeLa cells, the type of the cell death was evaluated using FACS analysis. Literary data from previous studies have shown that apoptosis was the dominant type of cell death induced with $\mathrm{CH}$ analogues (Ramirez-Tagle et al., 2016) (Fogaça et al., 2017)(Takac et al., 2018)(Abdelwahab, Abdul, Zain, \& Hadi, 2012). Apoptosis occurs as a defense mechanism in cells during immune reactions or in cells that are damaged by disease (Norbury \& Hickson, 2001). Apoptosis include morphological and biochemical changes of affected cells. These changes are characterized with cytoplasmic shrinkage, membrane blebbing, chromatin condensation, externalization of phosphatidylserine activation of caspases and breakdown of proteins. Apoptosis can be initiated via two major signaling pathways: the intrinsic (mitochondrial pathway) through the release of mitochondrial proteins such as cytochrome c into the cytosol; the extrinsic (death receptor pathway) through binding of death receptor ligands to corresponding death receptors such as TRAIL to TRAIL receptors. (Tamm, Schriever, \& Dörken, 2001)(Malhotra \& Kaufman, 2009). The results of the research by Abdelwahab correlated with our results. Namely, Abdelwahab et al. determined the type of cell death with $\mathrm{IC}_{50}$ values of the Zerumbone and cisplatin on HeLa cells after 48 h treatment (Abdelwahab et al., 2012). Their results showed that the percentage of apoptotic HeLa cells was significantly higher after $48 \mathrm{~h}$ treatment with Zerumboneand cisplatin compared with untreated HeLa cells. However, the literature data showed that chalcones induced both apoptosis and autophagy in tumor cells (S. Zhao et al., 2012)(Gao et al., 2016). As part of the research, we examined impact of autophagy on the percentage of apoptotic HeLa cells. The results of our study have shown that Co-treatment with CQ did not induced changes in the percentage of apoptotic cells and that the autophagy was not included in the mechanism of cytotoxicity of the investigated agents. The research by Abdelwahab et al., showed that Zerumbone induced different morphological changes in the HeLa cells (Abdelwahab et al., 2012). The chalcones induced apoptosis of the HeLa cells with morphological changes including shrinkage of the cells, loss of the shape cells and decrease in the number cells. The incubation with different concentrations of the $\mathrm{CH}$ results in a complete loss of the morphology of treated cells while untreated cells remain confluent throughout the incubation period. We herein reported for 
the first time anti-tumor effect $\mathrm{CH}$ and we showed that our previously synthesized chalcone had more effective antitumor effect compared to many other anti-tumor drugs.

\section{ACKNOWLEDGEMENTS}

This study was financially supported by Faculty of Medical Sciences, University of Kragujevac (JP14/17)Antitumorski efekat novosintetisanih analoga halkona na vijabilnost tumorskih ćelija in vitro. The authors wish to thank project called "Preklinička ispitivanja bioaktivnih supstanci (PIBAS)", registry number 41010 for support. We cordially thank for the help and courtesy of Suzana Popović (Faculty of Medical Sciences, University of Kragujevac, Serbia Center for Molecular Medicine and Stem Cell Research), prof. Zoran Ratković and dr Jovana Muškinja, Faculty of Chemistry, University of Kragujevac.

\section{REFERENCES}

1. Abdelwahab, S. I., Abdul, A. B., Zain, Z. N. M., \& Hadi, A. H. A. (2012) Zerumbone inhibits interleukin-6 and induces apoptosis and cell cycle arrest in ovarian and cervical cancer cells International Immunopharmacology 12(4):594-602. https://doi.org/10.1016/j.intimp.2012.01.014

2. Ahmed, F. F., Abd El-Hafeez, A. A., Abbas, S. H., Abdelhamid, D., \& Abdel-Aziz, M. (2018) New 1,2,4-triazole-Chalcone hybrids induce Caspase-3 dependent apoptosis in A549 human lung adenocarcinoma cells European Journal of Medicinal Chemistry 151:705722. https://doi.org/10.1016/j.ejmech.2018.03.073

3. Alibeiki, F., Jafari, N., Karimi, M., \& Peeri Dogaheh, H. (2017) Potent anti-cancer effects of less polar Curcumin analogues on gastric adenocarcinoma and esophageal squamous cell carcinoma cells Scientific Reports 7(1):1-9. https://doi.org/10.1038/s41598-017-02666-4

4. An, B., Zhang, S., Yan, J., Huang, L., \& Li, X. (2017) Synthesis, in vitro and in vivo evaluation of new hybrids of millepachine and phenstatin as potent tubulin polymerization inhibitors Organic and Biomolecular Chemistry 15(4):852-862. https://doi.org/10.1039/C6OB02507B

5. Ball, C., \& Madden, J. E. (2003) Update on cervical cancer screening: Current diagnostic and evidence-based management protocols Postgraduate Medicine 113(2):59-70. https://doi.org/10.3810/ pgm.2003.02.1375

6. Burmudžija, A. Z., Muškinja, J. M., Kosanić, M. M., Ranković, B. R., Novaković, S. B., Đorđević, S. B., ... Ratković, Z. R. (2017) Cytotoxic and Antimicrobial Activity of Dehydrozingerone based Cyclopropyl Derivatives Chemistry and Biodiversity 14(8). https://doi. org/10.1002/cbdv.201700077

7. Fogaça, T. B., Martins, R. M., Begnini, K. R., Carapina, C., Ritter, M., de Pereira, C. M. P., ... Collares, T. (2017)
Apoptotic effect of chalcone derivatives of 2-acetylthiophene in human breast cancer cells Pharmacological Reports 69(1):156-161. https://doi.org/10.1016/j. pharep.2016.10.003

8. Gao, S., Sun, D., Wang, G., Zhang, J., Jiang, Y., Li, G., ... Chen, L. (2016) Growth inhibitory effect of paratocarpin E, a prenylated chalcone isolated from Euphorbia humifusa Wild., by induction of autophagy and apoptosis in human breast cancer cells Bioorganic Chemistry 69:121-128. https://doi.org/10.1016/j. bioorg.2016.10.005

9. K. Sahu, N., S. Balbhadra, S., Choudhary, J., \& V. Kohli, D. (2012) Exploring Pharmacological Significance of Chalcone Scaffold: A Review Current Medicinal Chemistry 19(2):209-225. https://doi. org/10.2174/092986712803414132

10. Kim, M. J., Kadayat, T., Um, Y. J., Jeong, T. C., Lee, E. S., \& Park, P. H. (2015) Inhibitory effect of 3-(4-hydroxyphenyl)-1-(thiophen-2-yl) prop-2-en1-one, a chalcone derivative on MCP-1 expression in macrophages via inhibition of ROS and Akt signaling Biomolecules and Therapeutics 23(2):119-127. https:// doi.org/10.4062/biomolther.2014.127

11. Kolundžija, B., Marković, V., Stanojković, T., Joksović, L., Matić, I., Todorović, N., ... Joksović, M. D. (2014) Novel anthraquinone based chalcone analogues containing an imine fragment: Synthesis, cytotoxicity and anti-angiogenic activity Bioorganic and Medicinal Chemistry Letters 24(1):546-548. https://doi. org/10.1016/j.bmcl.2013.11.075

12. Kubra, I. R., Bettadaiah, B. K., Murthy, P. S., \& Rao, L. J. M. (2014) Structure-function activity of dehydrozingerone and its derivatives as antioxidant and antimicrobial compounds Journal of Food Science and Technology 51(2):245-255. https://doi.org/10.1007/s13197-0110488-8

13. Kuo, P.-C., Damu, A. G., Cherng, C.-Y., Jeng, J.-F., Teng, C.-M., Lee, E.-J., \& Wu, T.-S. (2005) Isolation of a natural antioxidant, dehydrozingerone from Zingiber officinale and synthesis of its analogues for recognition of effective antioxidant and antityrosinase agents. Archives of Pharmacal Research 28(5):518-528.

14. Lahsasni, S., Al Korbi, F., \& Aljaber, N. A.-A. (2014) Synthesis, characterization and evaluation of antioxidant activities of some novel chalcones analogues Chemistry Central Journal 8(1):32. https://doi.org/10.1186/1752153X-8-32

15. Li, X., Bau, T., \& Bao, H. (2018) FPOA induces apoptosis in HeLa human cervical cancer cells through a caspase-mediated pathway Oncology Letters 8357-8362. https://doi.org/10.3892/ol.2018.8380

16. Mahapatra, D. K., Bharti, S. K., \& Asati, V. (2015) Anti-cancer chalcones: Structural and molecular target perspectives European Journal of Medicinal Chemistry 98:69-114. https://doi.org/10.1016/j.ejmech.2015.05.004 
17. Malhotra, J. D., \& Kaufman, R. J. (2009) The Endoplasmic Reticulum and the Unfolded Protein Response Semin Cell Dev Biol 18(6):716-731. https://doi. org/10.1016/j.semcdb.2007.09.003.The

18. Muñoz, N., Bosch, X., de Sanjosé, S., Herrero, R., Castellsagué, X., Shah, K. V, ... Meijer, C. J. L. M. (2003) Epidemiologic classification of human papillomavirus types associated with cervical cancer $\mathrm{N}$ Engl J Med 348(6):518-527. https://doi.org/10.1056/NEJMoa021641

19. Muškinja, J., Ratkovi, Z., Rankovi, B., \& Kosani, M. (2016) Synthesis of O -Alkyl Derivatives of Dehydrozingerone Analogues Kragujevac Journal Science 38:97-106.

20. Naumovic, T., Miljus, D., Djoric, M., Zivkovic, S., \& Perisic, Z. (2015) Mortality from cervical cancer in Serbia in the period 1991-2011 Journal of B.U.ON. 20(1):231-234.

21. Norbury, C. J., \& Hickson, I. D. (2001) C r dna d367-401.

22. Ramirez-Tagle, R., Escobar, C. A., Romero, V., Montorfano, I., Armisén, R., Borgna, V., ... Echeverria, C. (2016) Chalcone-induced apoptosis through caspasedependent intrinsic pathways in human hepatocellular carcinoma cells International Journal of Molecular Sciences 17(2). https://doi.org/10.3390/ijms17020260

23. Taguchi, T., Nazneen, A., Abid, M. R., \& Razzaque, M. S. (2005) Cisplatin-Associated Nephrotoxicity and Pathological Events In Cellular Stress Responses in Renal Diseases (pp. 107-121). https://doi. org/10.1159/000086055

24. Takac, P., Kello, M., Pilatova, M. B., Kudlickova, Z., Vilkova, M., Slepcikova, P., ... Mojzis, J. (2018) New chalcone derivative exhibits antiproliferative potential by inducing $\mathrm{G} 2 / \mathrm{M}$ cell cycle arrest, mitochondrial-mediated apoptosis and modulation of MAPK signalling pathway Chemico-Biological Interactions 292(July):3749. https://doi.org/10.1016/j.cbi.2018.07.005

25. Tamm, I., Schriever, F., \& Dörken, B. (2001) Apoptosis: implications of basic research for clinical oncology. The Lancet Oncology 2(1):33-42. https://doi.org/10.1016/ S1470-2045(00)00193-5

26. Wu, W., Liu, Y., \& Zhu, D. (2010) л-Conjugated molecules with fused rings for organic field-effect transistors: Design, synthesis and applications Chemical Society Reviews 39(5):1489-1502. https://doi.org/10.1039/ b813123f

27. Zhang, B., Duan, D., Ge, C., Yao, J., Liu, Y., Li, X., \& Fang, J. (2015) Synthesis of xanthohumol analogues and discovery of potent thioredoxin reductase inhibitor as potential anticancer agent Journal of Medicinal Chemistry 58(4):1795-1805. https://doi.org/10.1021/ jm5016507

28. Zhao, L., Mao, L., Hong, G., Yang, X., \& Liu, T. (2015) Design, synthesis and anticancer activity of matrine-1H-1,2,3-triazole-chalcone conjugates Bioorganic and Medicinal Chemistry Letters 25(12):2540-2544. https://doi.org/10.1016/j.bmcl.2015.04.051

29. Zhao, S., Ma, C.-M., Liu, C.-X., Wei, W., Sun, Y., Yan, H., \& Wu, Y.-L. (2012) Autophagy inhibition enhances isobavachalcone-induced cell death in multiple myeloma cells. International Journal of Molecular Medicine 30(4):939-944. https://doi.org/10.3892/ ijmm.2012.1066. 